http://dx.doi.org/10.1590/0370-44672018720193

Francisco Junior Batista Pedrosa ${ }^{1,3}$

https://orcid.org/0000-0003-1185-7512

Maurício Guimarães Bergerman ${ }^{1,4}$

https://orcid.org/0000-0002-6843-3051

Juliana Segura-Salazar ${ }^{2,5}$

https://orcid.org/0000-0003-2758-7983

Homero Delboni Junior ${ }^{1,6}$

https://orcid.org/0000-0002-2856-7426

'Universidade de São Paulo - USP, Escola Politécnica, Engenharia de Minas e de Petróleo,

São Paulo - São Paulo - Brasil.

${ }^{2}$ Universidade Federal do Rio de Janeiro - UFRJ, Departamento de Engenharia Metalúrgica e de Materiais, Rio de Janeiro - Rio de Janeiro - Brasil.

E-mails: 3franciscopedrosa23@hotmail.com, ํmbergerman@usp.br, ${ }^{5}$ julianasegura@gmail.com, ${ }^{6}$ hdelboni@usp.br

\section{HPGR as alternative to fused alumina comminution route: an assessment of circuit simplification potential}

\author{
Abstract
}

A considerable portion of energy consumption and, as a consequence, operational costs in mineral processing, is associated with comminution. High Pressure Grinding Rolls (HPGR) are appealing for their energy efficiency and resulting lower operating costs. This article evaluates this technology as an alternative to the conventional fused alumina comminution route of a specific plant comprising a complex roll crushing circuit. Two fused alumina samples, called BT and TB, were submitted to HPGR (open circuit) and physical characterization (DWT, BBWI, bulk density, specific gravity) tests. In addition, simulations were conducted using JKSimMet ${ }^{\circledR} 6.0$ software, aiming to predict the performance of a closed circuit equipment and scale-up of an industrialscale unit. Product size distributions of the open circuit HPGR tests and closed circuit HPGR simulations were compared with the product size distribution required by the industrial comminution circuit. The required throughput was also evaluated. Results show that the alternative HPGR route provides a remarkable potential for circuit simplification, while considerably reducing the number of comminution equipments from 13 to 1 , which facilitates operational control and possibly reduces operating costs.

keywords: HPGR, fused alumina, comminution, process simulation.

\section{Introduction}

Comminution accounts for a significant share of energy consumption in ore processing plants (almost $80 \%$ in certain cases) and approximately $2 \%$ of the electric power generated worldwide (Abouzeid and Fuerstenau, 2009; NapierMunn, 2015). The pursuit of increased comminution efficiency is driven by the high production throughput required, poorer grades of ores, high steel con- sumption as a result of grinding ball and lining wear, and the low energy efficiency of conventional comminution technologies (Abouzeid and Fuerstenau, 2009). In such a context, HPGR (High Pressure Grinding Rolls) becomes an attractive option in terms of energy efficiency and cost effectiveness for processing certain ore types (Napier-Munn, 2015; Rashidi et al., 2017).
HPGR development is related to fundamental interparticle comminution studies conducted by Prof. Dr. Klaus Schönert (Schönert, 1979). In his research, Schönert concluded that, notwithstanding the higher energy efficiency in breaking single particles by compression, the breakage of a compressed bed of particles results in considerably higher energy efficiency than that obtained in 
tubular mills. A practical application of Schönert's results was a design consisting of two rollers coupled to a rigid structure. One of the rolls rotates in a fixed position, while the other roll rotates by moving linearly upon a hydraulic pressure system (Schönert, 1988). When fed between the rollers, particles enter a pre-grinding zone and then reach an

where $M$ is throughput (tph), $U$ is the circumferential roll speed $(\mathrm{m} / \mathrm{s}), \mathrm{L}$ is the roll length $(\mathrm{m}), \rho_{\mathrm{g}}$ is the flake density $\left(\mathrm{t} / \mathrm{m}^{3}\right), \mathrm{x}_{\mathrm{g}}$ is the operating roll gap $(\mathrm{m})$ and $\mathrm{c}$ is a correction factor.

Subsequently, with an aim to reduce the effect of equipment dimensions on throughput calculation, a specific throughput index was established (Rashidi et al., 2017). This parameter, which is characteristic of an HPGR's operation, is usually assumed as similar in both industrial and laboratory units and can be used to directly scale-up for the throughput of an industrial unit (Patzelt et al., 2000; Morley, 2006). The specific grinding force determines the product size distribution and is directly related to the specific comminution energy (Schönert, 1988; Patzelt et al., 2000; Daniel, 2002). Taking as a basis the aforementioned key HPGR design parameters, a number of mathematical models has been proposed in literature with an aim to predict HPGR behavior, particularly for the purpose of scaling-up for industrial units (Rashidi et al., 2017). The model developed by Morrell et al. (1997) is available in the JKSimMet ${ }^{\circledR}$ process simulation software and is comprised of three submodels: throughput, power, and prod- area in which interparticle breakage takes place on a bed under high compression. Such transfer is characterized by particle compaction and friction, resulting in a bulk density equivalent of up to $85 \%$ of the ore specific gravity. At the end of the process, the pressure is reduced and the particles leave the equipment in the form of flakes or free flow, as is the case of

$$
M=3600 \cdot U \cdot L \cdot \rho_{g} \cdot x_{g} \cdot c
$$

uct size distribution. The throughput sub-model uses the standard free flow version as described by the continuity equation (Equation 1). The power consumption component depends on the throughput being simulated and the specific comminution energy obtained experimentally. The product size distribution model is made up of three mechanisms or zones, which occur independently of each other in the HPGR: pre-grinding, edge effect, and compression effect.

Since the HPGR started to be manufactured on a commercial scale in the 1980s, it has found widespread application, especially in the cement industry, but also in the comminution of several ores, such as iron (crushed ore and pellet feed), diamond, copper, gold, platinum, and limestone, among others (Morley, 2006; Morley, 2010; Rashidi et al. 2017). However, its use in the processing of abrasive grains, such as fused alumina, has been little exploited in the scientific literature (Karimi and Djokoto, 2012). In this sense, the characteristics of HPGR have led the company Elfusa Geral de Eletrofusão to evaluate this equipment as an alternative to the conventional fused alumina comminution route, which is currently quartz (Schönert, 1988). Three key criteria have been established for the HPGR design: throughput, specific grinding force, and power consumption (Schönert, 1985). Throughput is influenced by the ore properties and equipment characteristics and may be defined by the continuity equation, represented by Equation 1 below (Morrell et al., 1997).

carried out by a staged crushing circuit followed by two parallel roll crushing circuits whose equipment is arranged according to a complex layout (as shown in Figure 1 below), which makes its operation and optimization a challenging task. Fused alumina, the focus of this article, is produced by fusion bauxite and additional elements in electric arc furnaces at a temperature of $2,050^{\circ} \mathrm{C}$. At the end of the process, the material is cooled down and forms large solid ingots, which require comminution to meet commercial particle size specifications (Jackson and Davim, 2011). Elfusa Geral de Eletrofusão roll crusher circuits 1 and 2, which comminute BT and TB alumina, respectively, are referred to herein as BT and TB circuits. These circuits operate individually processing different materials, while the staged crushing circuit which precedes them comminutes both materials in different periods. This article evaluates the potential use of HPGR as a replacement for the two previously described roll crusher circuits. Open circuit HPGR tests and computer simulations of HPGR were carried out. The latter was intended to predict the equipment performance operating in a closed circuit and scale it up into an industrial plant.

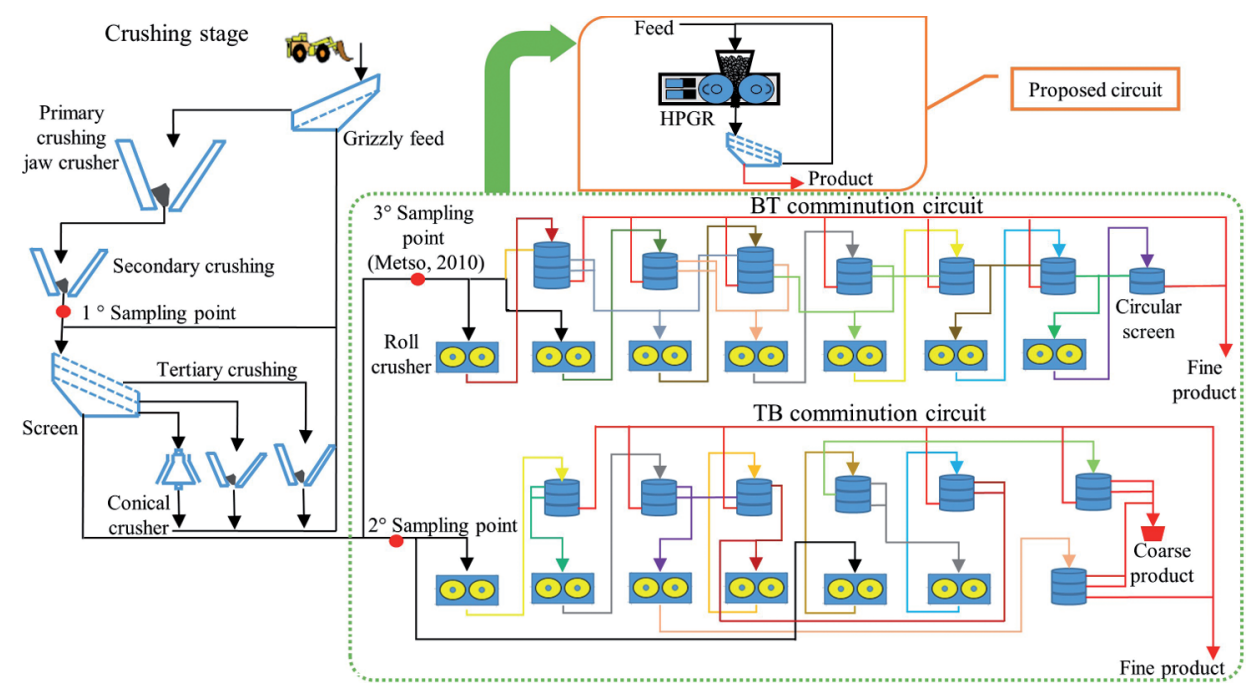

Figure 1

Conventional fused alumina comminution route and the proposed circuit. 


\section{Materials and methods}

\subsection{Study steps}

The present study began with the industrial sampling in the comminution circuit evaluated. Then the samples were homogenized, quartered and submitted to physical characterization and HPGR tests in Metso D1000 ${ }^{\mathrm{TM}}$. In parallel, the product size distribution required by the industrial circuit was determined from the grain production data. Additionally, presented herein are the results of pilot HPGR tests performed by Metso in 2010 on a sample obtained from the same comminution circuit with characteristics similar to those considered in this study. The HPGR product size distribution of both the D1000TM and the HRC TM $^{\text {TM }} 300$ (open circuit) were compared with the product size distributions required by the industrial circuit to evaluate if the HPGR would meet the product granulometry demand. Afterwards, in order to evaluate the performance of the HPGR in closed circuit, model fit and simulations were carried out using the simulator JKSimMet ${ }^{\circledR}$. The product size distribution from the closed circuit of HPGR (simulated) were compared to that required again, in order to evaluate the meeting the granulometry specifications demanded by the industrial circuit. Finally, a preliminary analysis of the simplification potential of the current circuit was carried out, through the use of HPGR. Figure 2 presents a flowchart of all stages of the development of this study.

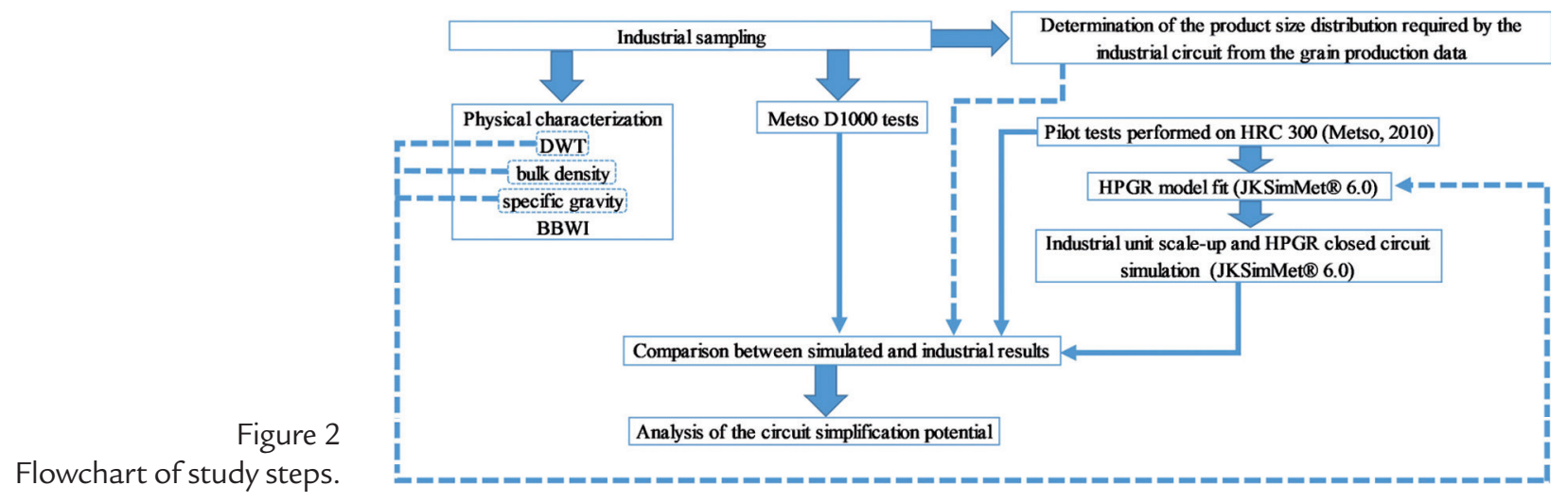

\subsection{Industrial sampling campaign and physical characterization}

Industrial sampling comprised of taking a sample in the secondary crushing product and feed of TB roll crusher circuit flows, as illustrated in Figure 1. The secondary crushing product was sampled with the aim of providing a coarse sample for the standard drop weight test and to evaluate the application of the HPGR in circuit, from tertiary crushing. This option, however, was disregarded, as it evaluated that the coarse feed could accelerate the wear of rolls. Nevertheless, this study presents the results of HPGR tests performed in coarse feed granulometry. BT fused alumina was taken from this sampling point. Feed flow of the TB roll crusher circuit was sampled considering HPGR as a replacement for this circuit, and from this point, TB fused alumina was taken. In addition, the sampling point for the study performed by Metso in 2010 is also presented in Figure 1.
This point was chosen considering HPGR as a replacement for the BT roll crusher circuit and the fused alumina sampled was BT. In this study, the HPGR was evaluated as a substitute for the BT and TB roll crusher circuits individually, although it is considered that a single unit would be able to meet the demands of the two circuits. In view of the great complexity of roll crushing circuits, including 14 screens and 30 different flows, and a wide variability of granulometry of its product over time, the product size distribution required by the industrial circuit was determined from the grain production data. These are traded as a function of retained mass by certain sieve meshes. One-year historical production data were used to establish product size distributions based on the daily production in each particle size range and then selecting maximum (coarser), minimum (finer) and the annual weighted average granulometric specification.

The physical characterization of the samples comprised the tests of particle size analysis, bulk density, specific gravity, Bond ball work index (BBWI), drop weight (DWT). Specific gravity was determined through the volumetric displacement method using a Chapman tube in accordance with NBR 9776 (Associação Brasileira de Normas Técnicas, 1987) and a hydrostatic balance. BBWI was calculated according to the Bond method (Bond, 1952) using a 150 $\mu \mathrm{m}$ test mesh. The standard Drop Weight Test (Napier-Munn et. al., 1999) was carried out on a BT oxide sample. Because TB oxide coarser particles were not available, a simplified method developed by Chieregati and Delboni Júnior (2002) was adopted, using the finer particle size fraction from the standard DWT test: $-16+13.2 \mathrm{~mm}$.

\subsection{HPGR tests, model fit and simulations}

HPGR tests were carried out using Metso's D1000 ${ }^{\mathrm{TM}}$ due to limited availability of fused alumina samples. This equipment, which simulates the operation of a $1 / 4$ turn of a HPGR with a diameter of $1 \mathrm{~m}$, requires a relatively small amount of sample and only allows the determination of the product size distribution as a func- tion of the specific grinding force. More details about D1000 ${ }^{\mathrm{TM}}$ and its methodology can be consulted in Pedrosa (2019). The pilot tests performed by Metso in 2010 were conducted in the HRC ${ }^{\mathrm{TM}}$ 300; additional information about this equipment and its methodology can be found in Oliveira (2015). All tests were carried out on fresh dry feeds, with an aim to simulate the operating conditions of the Elfusa industrial circuit. Table 1 presents a summary of operating conditions of HPGR tests reviewed herein. The initial gap was adjusted according to the feed top size and the possible expected operating gap. 


\begin{tabular}{|c|c|c|c|c|c|c|c|c|c|c|}
\hline Equipment & \multicolumn{6}{|c|}{$\mathrm{D} 1000^{\mathrm{TM}}$} & \multicolumn{4}{|c|}{$\mathrm{HRC}^{\mathrm{TM}} 300$} \\
\hline Roll diameter (m) & \multicolumn{6}{|c|}{$\begin{array}{c}\text { Simulates the operation of a } 1 / 4 \text { turn of a } \\
\text { HPGR with a diameter of } 1 \mathrm{~m} \text {. }\end{array}$} & \multicolumn{4}{|c|}{0.3} \\
\hline Roll length (m) & \multicolumn{6}{|c|}{0.15} & \multicolumn{4}{|c|}{0.15} \\
\hline Max. draw power (kW) & \multicolumn{6}{|c|}{ - } & \multicolumn{4}{|c|}{30} \\
\hline Fused alumina sample & \multicolumn{3}{|c|}{ TB } & \multicolumn{3}{|c|}{ BT } & \multicolumn{4}{|c|}{ BT } \\
\hline Specific grinding force $\left(\mathrm{N} / \mathrm{mm}^{2}\right)$ & 1 & 3 & 4 & 2 & 3 & 4 & 1 & 2 & 3 & 4 \\
\hline Feed condition & fresh & fresh & fresh & fresh & fresh & fresh & fresh & fresh & fresh & fresh \\
\hline Moisture (\%) & 0 & 0 & 0 & 0 & 0 & 0 & 0 & 0 & 0 & 0 \\
\hline Initial gap (mm) & 12 & 12 & 12 & 19 & 19 & 12 & 2 & 2 & 2 & 2 \\
\hline Feed top size (mm) & 19 & 19 & 19 & 37.5 & 37.5 & 37.5 & 19 & 19 & 19 & 19 \\
\hline Mass requirement $(\mathrm{kg})$ & 10 & 10 & 10 & 10 & 10 & 10 & 200 & 200 & 200 & 200 \\
\hline
\end{tabular}

Table 1

Operating conditions of HPGR tests.

In the case of the D1000 ${ }^{\mathrm{TM}}$ equipment, there are no rolls, but a section (similar to an arc) representing the rollers, so the diameter and length indicated in Table 1 for this equipment refers to this section.

Morrell's phenomenological model was chosen to represent the HPGR performance using a JKSimMet ${ }^{\circledR}$ v.6.0 process simulator. This model predicts the product size distribution, the throughput and power consumption of the industrial equipment based on the dimensions and operating conditions of a bench or pilot HPGR and the material properties (Morrell et al., 1997). In this

where $\mathrm{x}_{\mathrm{g}}$ is the operational gap $(\mathrm{mm})$, $\mathrm{D}$ is the roll diameter $(\mathrm{m})$ and $\rho_{\mathrm{g}}$ is the flake density $\left(t / \mathrm{m}^{3}\right)$. The appearance functions obtained from the DWT, for both samples, besides representing the breakage of individual particles, were also used to represent the bed compression breakage means of the extrapolation of the parameter $t_{10}$ to a value of $50 \%$. Such simplification

\section{Results and discussion}

\subsection{Material characterization}

Table 2 presents the results of physical characterization tests. Both types of alumina are deemed high hardness ones (BBWI $>20 \mathrm{kWh} / \mathrm{t}$ ). Regarding the mechanism of impact breakage of single particles (DWT), the BT alumina is typically classified as low breakage resistant. The TB alumina study, Morrell's model was calibrated on the basis of operating data from a test conducted on the HRCTM 300 with a specific grinding force of $3 \mathrm{~N} / \mathrm{mm}^{2}$ (Table 1), and appearance functions derived from DWT tests for TB and BT oxides. The model had to be calibrated with data obtained from a HPGR pilot test performed in a sample with similar characteristics to this study, due to the limited amount of samples available, which made it impossible to carry out new pilot tests, since these require a relatively high amount of sample. This premise assumed is justified by the relative homogeneity of the fused alumina as

$$
x_{g}=\frac{\dot{m}_{\text {feed }} \cdot D}{\rho_{g} \cdot 3.6} \cdot \frac{\dot{m}_{\text {flake }}}{\dot{m}_{\text {feed }}}
$$

may be justified according to Tondo's (1997) extensive investigation, whose conclusion was that the breakage resulting from bed compression does not differ much from the impact breakage mechanism (Daniel, 2002). The modeling also used the bulk and flake density, the latter assumed as $80 \%$ of the specific gravity ore (Daniel, 2002). After the model calibration, simulations to comminution over time, as verified by Menegatto and Bergerman (2015), since this material is produced artificially under controlled conditions in the fusion process. Due to the unavailability of the operational gap measurement of the HPGR test used for model calibration, this parameter had to be calculated from Equation 2 (Klymowsky et al., 2002). In this case the extrusion and slippage effects of the material were excluded, assuming that the specific throughput obtained from the feed rate $\left(\dot{m}_{\text {feed }}\right)$ would be similar to the specific throughput calculated from the flake $\left(\dot{m}_{\text {flake }}\right)$, as demonstrated by Daniel (2002).

were conducted to predict the HPGR performance in a closed circuit and to industrial unit scale-up. Because the industrial processing plant requires a relatively low tonnage (80 tons per day per circuit), dimensions and operating conditions from the smallest HPGR version commercially available from Metso, the HRC ${ }^{\mathrm{TM}} 800(0.8 \times 0.5 \mathrm{~m})$, were used. could be considered as high impact resistant. However, it should be noted that parameters $\mathrm{A}$ and $\mathrm{b}$ reported for this material are based on the simplified DWT procedure. The lack of coarse particles in the TB alumina samples limited the test just to the finer particle size range $(-16+13.2 \mathrm{~mm})$, in which the particle breakage resistance tends to be higher than the average standard ranges of DWT test. This can be explained by the smaller number and size of pores when compared to coarser particles, so that it is necessary to apply a higher stress to break finer particles (Tavares, 2007). 
Table 2

Physical characterization test results.

\begin{tabular}{c|c|c|c|c|c|c|c|c|c}
\multirow{2}{*}{$\begin{array}{c}\text { Fused } \\
\text { alumina }\end{array}$} & \multicolumn{2}{|c|}{ Bulk density } & \multicolumn{2}{|c|}{ Specific gravity } & \multicolumn{2}{c|}{ BBWI } & \multicolumn{3}{c}{ DWT } \\
\cline { 2 - 11 } & Average & $\begin{array}{c}\text { Relative } \\
\text { standard } \\
\text { deviation } \\
(\%)\end{array}$ & $\begin{array}{c}\text { Average } \\
\left(\mathrm{g} / \mathrm{cm}^{3}\right)\end{array}$ & $\begin{array}{c}\text { Relative } \\
\text { standard } \\
\text { deviation } \\
(\%)\end{array}$ & $\begin{array}{c}\text { Average } \\
(\mathrm{kWh} / \mathrm{t})\end{array}$ & $\begin{array}{c}\text { Relative } \\
\text { standard } \\
\text { deviation } \\
(\%)\end{array}$ & $\mathrm{A}$ & $\mathrm{b}$ & $(\mathrm{A} . \mathrm{b})$ \\
\hline BT & 2.10 & 4.30 & 3.60 & 3.70 & 28.9 & - & 64.36 & 1.38 & 88.82 \\
\hline TB & 2.60 & 1.40 & 3.80 & 0.50 & 26.0 & 1.10 & 63.11 & 0.60 & 37.87 \\
\hline
\end{tabular}

\section{2 $\mathrm{D} 1000^{\mathrm{TM}}$ and $\mathrm{HRC}^{\mathrm{TM}} 300$ tests}

Results of open circuit tests using the units D1000 ${ }^{\mathrm{TM}}$ and HRC $\mathrm{HM}^{\mathrm{TM}} 300$ (Metso, 2010) are given in Figure 3 and Table 3. As expected, there was a reduction in the product size distribution with increasing specific grinding force. Tests on BT alumina (with two different samples with similar characteristics) under the same specific grinding force in different HPGR

Figure 3

Feed and product

size distribution based on tests with BT oxide (a) and TB oxide (b). units and using different feed size distributions result in relatively similar product size distributions. This could be explained by a relatively homogeneous material produced under controlled fusion conditions. According to Daniel (2002), Tondo's (1997) experiments suggested that the breakage of homogenous materials, such as quartz and marble, would not be influenced by the

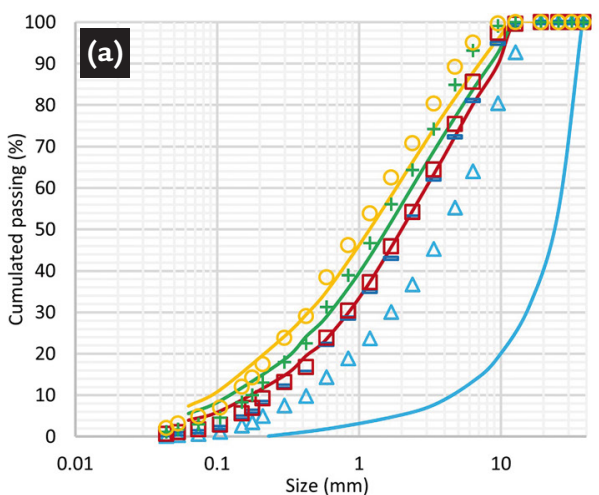

\footnotetext{
$\triangle \quad$ HRC 300 feed $\quad$ - HRC 300 product $1 \mathrm{~N} / \mathrm{mm}^{2}$

口 HRC 300 product $2 \mathrm{~N} / \mathrm{mm}^{2}+$ HRC 300 product $3 \mathrm{~N} / \mathrm{mm}^{2}$ HRC 300 product $4 \mathrm{~N} / \mathrm{mm}^{2} \longrightarrow$ D1000 feed

D1000 product $2 \mathrm{~N} / \mathrm{mm}^{2} \longrightarrow$ D1000 product $3 \mathrm{~N} / \mathrm{mm}^{2}$ D1000 product $4 \mathrm{~N} / \mathrm{mm}^{2}$
}

feed particle distribution, roll speed, and initial roll gap. According to the author, all particles undergo a similar breakage mechanism according to a defined pattern, which leaves the amount of applied energy as the only factor. This particularity should be further investigated in future research, since data from only three trials in each equipment are inconclusive.

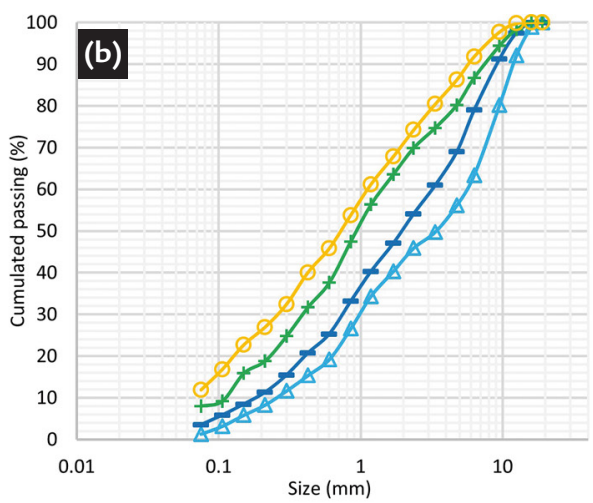

$\begin{array}{ll}\longrightarrow \triangle \text { D1000 feed } & \text { D1000 product } 1 \mathrm{~N} / \mathrm{mm}^{2} \\ \square \text { D1000 product } 3 \mathrm{~N} / \mathrm{mm}^{2} \longrightarrow \text { D1000 product } 4 \mathrm{~N} / \mathrm{mm}^{2}\end{array}$

Table 3

Summary of HPGR test results.

\begin{tabular}{|c|c|c|c|c|c|c|c|c|c|c|}
\hline $\begin{array}{l}\text { Fused } \\
\text { alumina }\end{array}$ & HPGR & $\begin{array}{c}\text { Specific } \\
\text { grinding } \\
\text { force } \\
\left(\mathrm{N} / \mathrm{mm}^{2}\right)\end{array}$ & $\begin{array}{c}\text { Specific } \\
\text { throughput } \\
\left(\text { t.s } / \mathrm{hm}^{3}\right)\end{array}$ & $\begin{array}{l}\text { Power draw } \\
\qquad(\mathrm{kW})\end{array}$ & $\begin{array}{c}\mathrm{F}_{80} \\
(\mathrm{~mm})\end{array}$ & $\begin{array}{c}\mathrm{F}_{50} \\
(\mathrm{~mm})\end{array}$ & $\begin{array}{c}P_{80} \\
(\mathrm{~mm})\end{array}$ & $\begin{array}{c}P_{50} \\
(\mathrm{~mm})\end{array}$ & $\begin{array}{l}\% \text { passing } \\
0.075 \mathrm{~mm}\end{array}$ & $\begin{array}{l}\text { Red. ratio } \\
\left(\mathrm{F}_{50} / \mathrm{P}_{50}\right)\end{array}$ \\
\hline \multirow{7}{*}{ BT } & \multirow{3}{*}{$\mathrm{D} 1000^{\mathrm{TM}}$} & 2 & - & - & 32.2 & 23.6 & 6.3 & 2.3 & 4.6 & 10.3 \\
\hline & & 3 & - & - & 32.2 & 23.6 & 5.6 & 1.8 & 6.5 & 13.1 \\
\hline & & 4 & - & - & 32.2 & 23.6 & 4.6 & 1.2 & 8.5 & 19.6 \\
\hline & \multirow{4}{*}{$\mathrm{HRC}^{\mathrm{TM}} 300$} & 1 & 236.0 & 3.8 & 9.4 & 4.0 & 6.1 & 2.2 & 1.3 & 1.8 \\
\hline & & 2 & 226.3 & 7.5 & 9.4 & 4.0 & 5.5 & 2.0 & 1.8 & 2.0 \\
\hline & & 3 & 223.0 & 11.3 & 9.4 & 4.0 & 4.1 & 1.4 & 3.0 & 2.9 \\
\hline & & 4 & 234.0 & 15.0 & 9.4 & 4.0 & 3.3 & 1.0 & 4.9 & 4.0 \\
\hline \multirow{3}{*}{ TB } & \multirow{3}{*}{$\mathrm{D} 1000^{\mathrm{TM}}$} & 1 & - & - & 9.5 & 3.4 & 6.5 & 2.0 & 3.6 & 1.7 \\
\hline & & 3 & - & - & 9.5 & 3.4 & 4.7 & 0.9 & 8.0 & 3.8 \\
\hline & & 4 & - & - & 9.5 & 3.4 & 3.3 & 0.7 & 11.9 & 4.9 \\
\hline
\end{tabular}


Data given in Table 3 show that tests conducted on the D1000 ${ }^{\mathrm{TM}}$ unit produced the largest amount of fines $(0.075 \mathrm{~mm}$ passing) in the product, when compared with HRC ${ }^{\mathrm{TM}} 300$ tests. This fact is assumed to be related to the presence of flanges on the roll sides, which are found only in the D1000 ${ }^{\mathrm{TM}}$ unit. Oliveira (2015) maintains that such flanges improve the pressure distribution along the rolls with the resulting increase in ore interlocking in

\subsection{Closed circuit simulation}

Closed circuit simulations were conducted based on the product size specification required by the industrial circuit. the compression zone, which minimizes the edge effect. This might increase the degree of particle comminution, which, in the case of this study, is enhanced in the finer size fractions of the product. Moreover, it can be seen that the specific throughput is reduced and the power consumption rises with the increase in the specific grinding force, which is in line with literature (Schönert, 1988). Also, it should be pointed out that no product in any test experienced flake formation, which may be explained by the lack of moisture in the material, as it comes from electrofusion furnaces. This is an advantage from the operational and design standpoints, as flake formation may require additional equipment for it de-agglomeration, which impacts the operating and investment costs (Schönert, 1988; van der Meer and Gruendken, 2010) and the excess feed moisture may considerably reduce the equipment throughput (Saramak and Kleiv, 2013).
Table 4 shows the simulation results, while Figure 4 presents a comparison between the product size distribution from the open circuit HPGR tests and simulated closed circuit and the required product size specifications.

Table 4

Closed circuit simulation results.

\begin{tabular}{|c|c|c|c|c|c|c|c|c|}
\hline $\begin{array}{c}\text { Comminution } \\
\text { circuit }\end{array}$ & $\begin{array}{c}\text { Closing } \\
\text { sieve }(\mathrm{mm})\end{array}$ & $\begin{array}{l}\text { Circuit throughput } \\
\text { (tph) }\end{array}$ & $\begin{array}{l}\text { Rolls speed } \\
(\mathrm{m} / \mathrm{s})\end{array}$ & $\begin{array}{c}\text { HPGR } \\
\text { throughput (tph) }\end{array}$ & $\begin{array}{c}\text { Power } \\
\text { draw }(\mathrm{kW})\end{array}$ & $\begin{array}{c}\text { Ecs } \\
(\mathrm{kWh} / \mathrm{t})\end{array}$ & $\begin{array}{c}\text { Circuit } P_{80} \\
(\mathrm{~mm})\end{array}$ & $\begin{array}{c}\text { HPGR selected } \\
\mathrm{D} \times \mathrm{L}(\mathrm{m})\end{array}$ \\
\hline \multirow{3}{*}{ BT } & 3.35 & 30 & 1.177 & 104.9 & 140.0 & 1.33 & 2.145 & \multirow{5}{*}{$\begin{array}{c}\mathrm{HRC}^{\mathrm{TM}} \\
800(0.8 \times 0.5)\end{array}$} \\
\hline & 1.4 & 20 & 1.153 & 102.8 & 137.1 & 1.33 & 1.016 & \\
\hline & 0.5 & 15 & 1.252 & 111.6 & 148.8 & 1.33 & 0.433 & \\
\hline \multirow{2}{*}{ TB } & 4.75 & 30 & 0.956 & 85.2 & 114.0 & 1.33 & 2.485 & \\
\hline & 1.4 & 20 & 1.081 & 96.4 & 128.7 & 1.33 & 1.057 & \\
\hline
\end{tabular}
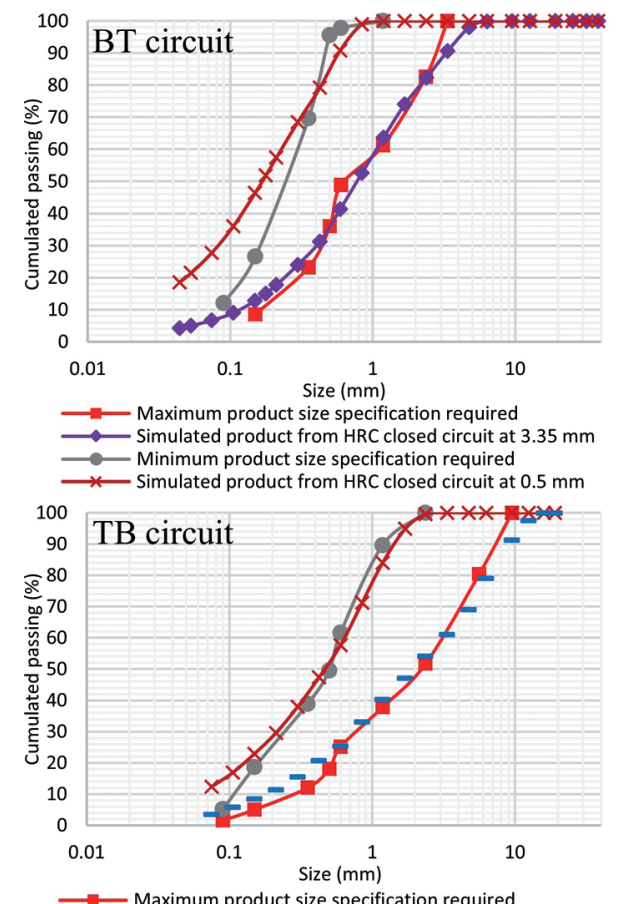

- Maximum product size specification required - D1000 product $1 \mathrm{~N} / \mathrm{mm}^{2}$ (open circuit) - Minimum product size specification required — Simulated product from HRC closed circuit at $1.40 \mathrm{~mm}$

Results presented in Figure 4 show that the minimum and maximum product size specifications required by the BT circuit are met by closing the HPGR circuit and using $3.35 \mathrm{~mm}$ and $0.5 \mathrm{~mm}$ screens. The minimum product

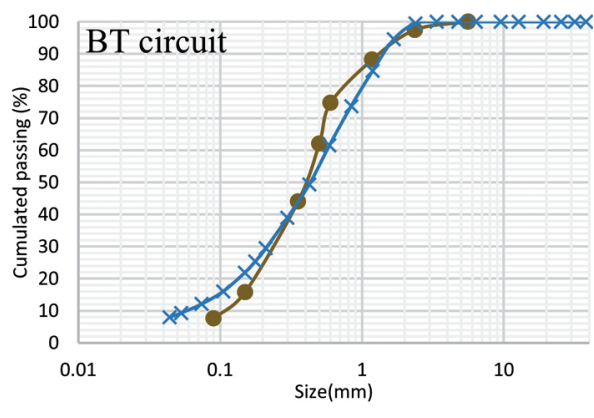

$\longrightarrow$ Annual average product size specification required

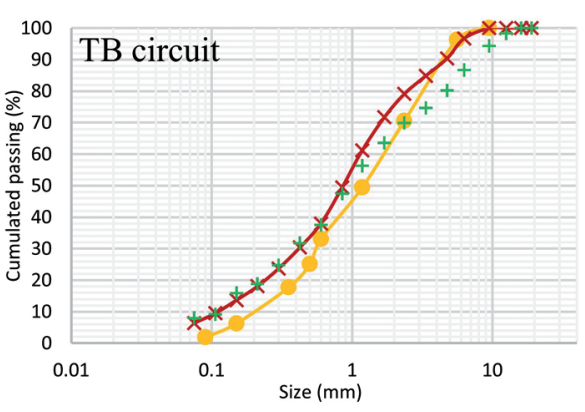

- Annual average product size specification required * Simulated product from HRC closed circuit at $4.75 \mathrm{~mm}$ + D1000 product $3 \mathrm{~N} / \mathrm{mm}^{2}$ (open circuit)

size specification required by the $\mathrm{TB}$ circuit is also met by the HPGR circuit with $1.40 \mathrm{~mm}$ screen. In addition, it can be seen that the annual average product size specification required by both circuits are satisfied by closing the
Figure 4 Comparison between product size distribution required by $\mathrm{BT}$ and TB comminution circuits and those obtained from tests and HPGR simulations.

HPGR circuit and using $1.40 \mathrm{~mm}$ and $4.75 \mathrm{~mm}$ screens for the BT and TB circuits, respectively. However, it must be noted that the annual average product size specification required by the TB circuit could be met in a relatively satisfac- 
tory manner by the HPGR operating in open circuit and using a specific grinding force of $3 \mathrm{~N} / \mathrm{mm}^{2}$. The maximum product size specification required by the TB circuit does not need the circuit to be closed. Instead, it is met by an open HPGR circuit operating with a specific grinding force of $1 \mathrm{~N} / \mathrm{mm}^{2}$. It must be stressed that, although the minimum product size specification P80 for the BT circuit is met by the closed HPGR circuit, a significantly higher amount of fines is generated, which is inherent to this equipment, when compared to

\subsection{Circuit simplification potential}

The meeting of the product size distribution and throughput shows the high potential of the HPGR

\section{Table 5}

Comparison between HPGR and traditional routes from the standpoint of number of equipment. Taking into consideration only comminution equipment.

The Table 5 figures point to a great potential for circuit simplification. In terms of the number of comminution units, the HPGR route proposes a reduction from 13 to 1 . This would have a significant impact in terms of operating costs, including maintenance, labor, and possibly energy. Another positive aspect of circuit simplification is how easily it can be controlled and optimized. The reduction in the number of units and, as a consequence, flows make sampling a much simpler task. Also, samples may be taken at a higher frequency, enabling to assess the best operating scenario to meet a given demand. As the circuit operation is not fixed and can be adapted to different

\section{Conclusions}

Using HPGR as an alternative route for fused alumina comminution is a promising solution in terms of circuit simplification. In the case of this specific project, both product size distribution and throughput requirements have been met, which results in a remarkable circuit simplification, including a reduction in the number of equipment units from 13 to 1 . This has impacts on operating, maintenance, and labor costs and facilitates the operation and conventional comminution technologies, such as roll crushers. Therefore, should this specificity be deemed a problem for a potential application, a whole campaign of tests in a closed HPGR circuit should be evaluated while optimizing operating variables, with an aim to determine which conditions are most suited to the specific process requirements. Regarding the throughput simulation to meet the throughput required by the 80 ton/day circuit, it was necessary to define different scenarios of circuit feed due to the speed range

technology as an alternative to the conventional fused alumina comminution route using roll crushers. Table limitation of the selected equipment ( 0.6 to $1.33 \mathrm{~m} / \mathrm{s}$ ) and the large circulating load variability as a result of the closing mesh used. The circuit throughput variation will have direct implications on the number of working hours and even in the worst scenario (15 tons per hour), the equipment would operate for just 5.3 hours, which means less than one work shift. Thus, because of the large throughput margin of the selected HPGR, one single unit could meet two conventional circuits based on multiple-stage roll crushers.

5 compares these circuits in terms of the number of equipment units and installed power.

\begin{tabular}{c|c|c|c|c|c} 
& $\begin{array}{c}\text { Comminution } \\
\text { equipment }\end{array}$ & Units & $\begin{array}{c}\text { Dimensions } \\
\mathrm{D} \times \mathrm{L}(\mathrm{m})\end{array}$ & Manufacturer & $\begin{array}{c}\text { Installed } \\
\text { power draw } \\
(\mathrm{kW})\end{array}$ \\
\hline $\begin{array}{c}\text { Conventional } \\
\text { route }\end{array}$ & Roll Crushers & 13 & $0.55 \times 0.44$ & Tavamac & 239.1 \\
\hline HPGR route & HPGR & 1 & $0.80 \times 0.50$ & Metso & 220.6 \\
\hline
\end{tabular}

product sizes and throughput requirements, the HPGR production route offers the advantage of changing such parameters in a more efficient manner than the conventional route by adjusting the roll speed, operating pressure, and circuit closing mesh. In the case of roll crusher circuits, the throughput and product size distribution are changed by starting up or shutting down equipment units and flows and, similarly to what happens in the HPGR, also by changing screen meshes, although on a much larger scale. It is recommended that an economic analysis should be made on the HPGR route for this specific application. Therefore, it is essential to determine the economic trade-off between the HPGR route and the conventional roll crusher route in terms of energy, labor, and maintenance costs. The latter is affected mainly by the need to change the roll lining. It is a well-known fact that fused alumina is highly abrasive and, as a result, excess lining wear is an inherent feature of comminution circuits used to process this material. Even though this factor could be deemed a potential limitation for an HPGR circuit, one should bear in mind that this kind of equipment is already used to comminute silicon carbide (Karimi and Djokoto, 2012), which is also used to manufacture synthetic abrasive grains and whose abrasiveness is as high as that of fused alumina. optimization activities, as sampling procedures are much simpler. This investigation is a pre-feasibility study with a focus on determining the potential of HPGR to meet the needs of this specific application. A more detailed study should be carried out to address energy consumption, roll lining wear, and whether the product quality meets the customer specification. The innovative nature of the proposed process route deserves to be highlighted. Although the
HPGR route has already been applied in the silicon carbide industry, there is no record of its use in fused alumina comminution circuits. Another important aspect derived from this study is a simplified HPGR test method using the Metso D1000 ${ }^{\mathrm{TM}}$ device, which allows predicting the product size distribution from a relatively small amount of material; a great advantage in the early development stages of projects with limited sample availability. 


\section{Acknowledgements}

The authors thanks Elfusa Geral de Eletrofusão, Metso do Brasil, HDA Serviços
LTDA, and Laboratório de Tratamento de

Minérios e Resíduos Industriais - EPUSP.

\section{References}

ABOUZEID A. M., FUERSTENAU D. W. Grinding of mineral mixtures in high-pressure grinding rolls. International Journal of Mineral Processing, v. 93, p. 59-65, 2009.

ASSOCIAÇÃO BRASILEIRA DE NORMAS TÉCNICAS. NBR 9776: Determinação da massa específica de agregados miúdos por meio do frasco de Chapman. Rio de Janeiro, 1987. $4 \mathrm{p}$.

BOND, F.C. The third theory of comminution. Transactions of American Institute of Mining and Metallurgical Engineers, v. 193, n. 5, p. 484-494, 1952.

CHIEREGATI, A. C., DELBONI JÚNIOR, H. Novo método de caracterização tecnológica para cominuição de minérios. In: ENCONTRO NACIONAL DE TRATAMENTO DE MINÉRIOS E METALURGIA EXTRATIVA, 19., 2002, Recife. Anais... Recife: UFPE, 2002. p. 95-102.

DANIEL, M. J. HPGR model verification and scale-up. Brisbane: University of Queensland, 2002. 203 p. (Dissertação de Mestrado).

JACKSON, J. M., DAVIM, P. J. Abrasive tools and bonding systems machining with abrasives. In: JACKSON J. M., DAVIM, P. J. Machining with abrasives. New York: Springer, 2011. p. 1-72.

KARIMI, H. R., DJOKOTO, S. S. Instrumentation and modeling of high-pressure roller crusher for silicon carbide production. The International Journal of Advanced Manufacturing Technology, v. 62, p. 1107-1113, 2012.

KLYMOWSKY, R., PATZELT, N., KNECHT, J., BURCHARDT, E. Selection and sizing of high pressure grinding rolls. In: MULAR, A.L., HALBE, D. N., BARRATT, D.J. Mineralprocessing plantdesign, practice, and control.Proceedings... Littleton: SME, 2002. p. 636-668.

MENEGATTO, M. S., BERGERMAN, M. G. Otimização do circuito de cominuição da Elfusa Geral de Eletrofusão. In: ENCONTRO NACIONAL DE TRATAMENTO DE MINÉRIOS E METAluRgiA EXTRATIVA, 26., 2015, Poços de Caldas. Anais... Poços de Caldas: UNIFAL, 2015.

MORLEY, C. HPGR-FAQ. The Journal of The Southern African Institute of Mining and Metallurgy, v. 110, pp. 107-115, 2010.

MORLEY, C. High pressure grinding rolls: a technology review. In: KAWATRA, S. K. Advances in comminution. Littleton: SME, 2006. p. 15-39.

MORRELL, S., SHI, F., TONDO, L. A. Modelling and scale-up of high pressure grinding rolls. In: INTERNATIONAL MINERAL PROCESSING CONGRESS (IMPC), 20. Aahen. Proceedings... Aahen: Clausthal-Zellerfeld GDMB, 1997. p. 129-140.

NAPIER-MUNN T. J. Is progress in energy-efficient comminution doomed? Minerals Engineering, v. 73, p. 1-6, 2015.

NAPIER-MUNN, T. J., MORRELL, S., MORRISON, R. D., KOJOVIC, T. Mineral comminution circuits: their operation and optimization. Indooroopilly: Julius Krusttschnitt Mineral Research Centre, 1999. 413 p.

OLIVEIRA, R. N. M. Análise do desempenho do HRC ${ }^{T M}$ HPGR em circuito piloto. (2015). São Paulo: Escola Politécnica, Universidade de São Paulo, 2002. 173 p. (Dissertação Mestrado).

PATZELT, N., KNECHT, J., BURCHARDT, E., KLYMOWSKY, R. Challenges for high pressure grinding in the New Millennium. In: MILL OPERATORS CONFERENCE, 7. Kalgoorlie: 2000. Proceedings... Kalgoorlie: Carlton, Vic.: Australasian Institute of Mining and Metallurgy, 2000. p. 47-55.

PEDROSA, F. J. B. O high pressure grinding rolls como alternativa à cominuição de óxido de alumínio eletrofundido: uma avaliação do potencial de simplificação de um circuito. São Paulo: Escola Politécnica, Universidade de São Paulo, 2019. 155 p. (Dissertação Mestrado).

RASHIDI, S., RAJAMANI, R. K., FUERSTENAU, D. A Review of the modelling of high pressure grinding rolls. Kona Powder and Particle Journal, n. 134, p. 125-140, 2017.

SARAMAK, D., KLEIV, R. A. The effect of feed moisture on the comminution efficiency of HPGR circuits. Minerals Engineering, v. 43, p. 105-111, 2013.

SCHÖNERT, K. A first survey of grinding with high compression roller mills. International Journal of Mineral Processing, v. 22, p. 401- 412, 1988. 
SCHÖNERT, K. Sizing of high pressure twin roll mills. Zement-Kalk-Gips, v. 38, n. 12, p. 728-730, 1985.

SCHÖNERT, K. Energetische aspekte des zerkleinerns spröder stoffe. Zement-Kalk-Gibs, v. 32. p. 1-9, 1979.

TAVARES, L. M. Breakage of single particles: quasi-static. In: SALMAN, A. D., GHADIRI, M., HOUNSLOW, M. J. Handbook of powder technology. Amsterdam: Elsevier B.V., 2007. p. 3-68.

TONDO, L. A. Phenomenological modelling of size reduction performed by a high pressure roll mill. 1997. 219 p. Brisbane: University of Queensland, 1997. Thesis (Master's degree).

VAN DER MEER, F. P., GRUENDKEN, A. Flowsheet considerations for optimal use of high pressure grinding rolls. Minerals Engineering, v. 23, p. 663-669, 2010.

Received: 16 December 2018 - Accepted: 29 April 2019. 